MORPHOLOGICAL IDENTIFICATION OF BACTERIA ISOLATED FROM MUSHROOM BAGLOG AND ITS

EFFECT ON SHIITAKE (Lentinula edodes (Berk.) Pegler) AND REISHI (Ganoderma lucidum (Curtis) P. Karst)

MYCELIAL GROWTH

Ni Kadek Emi Sintha Dewi, I Gede Putu Wirawan, Made Sritamin

\title{
MORPHOLOGICAL IDENTIFICATION OF BACTERIA ISOLATED FROM MUSHROOM BAGLOG AND ITS EFFECT ON SHIITAKE (Lentinula edodes (Berk.) Pegler) AND REISHI (Ganoderma lucidum (Curtis) P. Karst) MYCELIAL GROWTH
}

\author{
Ni Kadek Emi Sintha Dewi, I Gede Putu Wirawan*, and Made Sritamin \\ Faculty of Agriculture, Udayana University \\ Jl. PB. Sudirman, Denpasar, Bali 80852, Indonesia \\ *Corresponding author: igpwirawan@unud.ac.id
}

\begin{abstract}
Reishi (Ganoderma lucidum (Curtis) P. Karst) and shiitake (Lentinula edodes (Berk.) Pegler) mushrooms have high economic value and contain bioactive metabolites that provide heatlh benefits. Shiitake mushrooms have a delightfully unique taste as an edible mushroom. Mushroom production can be increased by utilizing microbes known as MGPB (Mushroom Growth Promoting Bacteria). This study aimed to determine the presence of bacteria associated with shiitake and reishi mushrooms in the baglog and determine how these bacteria influence the growth of shiitake and reishi mycelium. Bacteria was isolated from the mushroom baglog then were purified and centrifuged to obtain the cell-free extract. Furthermore, the bacterial cell-free extracts were poured on PDA media, then shiitake and reishi mycelium were inoculated to test the effect of bacteria isolates on fungal growth. The results showed that three isolates have the potential as MGPB in reishi mushroom, i.e., isolate S1C, S1D, and S2A. Reishi mycelium grown on isolate S2A achieved the fastest maximum growth on day 6th. In shiitake mushroom, it was seen that all isolates showed a negative effect on mycelium growth. Shiitake mycelium in isolate S1C, S1D, S2A, and S2B were seen to form a clear zone on PDA medium.
\end{abstract}

Keywords: Shiitake, Reishi, bacteria, MGPB

\section{INTRODUCTION}

Shiitake mushroom (Lentinula edodes (Berk.) Pegler) has high economic value and delightfully unique taste. Shiitake contains bioactive metabolites wih cholesterollowering and antitumor properties, such as eritadenine (Duran-Rivera et al., 2020) and polysaccharides lentinan (Ruthes et al., 2016). Moreover, reishi mushroom
(Ganoderma lucidum (Curtis) P.Karst) has been known as herbal medicine that has antidiabetic (Vitak et al., 2017) and anticancer properties (Skolastika, 2019).

Based on Badan Pusat Statistik (2019), mushroom yields have decreased from 2016 to 2018. On the other hand, mushroom consumption in Indonesia has increased 
every year (Direktorat Jenderal Hortikultura, 2017). Thus it is necessary to increase the yield and production of mushrooms. Fungal growth can be increased by utilizing MGPB (Mushroom Growth Promoting Bacteria). The use of microbes as a substitute for fertilizers can reduce the use of chemicals and can preserve the environment according to the concept of sustainable agriculture.

Several bacteria have been identified as MGPB, as reported by Febriansyah et al. (2018), that B. cereus, Acinetobacter pittii, and $B$. aryabhattai produced IAA and act as MGPB. Apart from stimulating the growth of fungal mycelium, some bacteria are known as pathogens in fungi; for instance, Pseudomonas tolaasii cause brown blotch disease on cultivated Agaricus bisporus (Abou-Zeid, 2012).

Therefore, the objective of this study was to determine the effect of bacteria associated in the fungal baglog on the growth of shiitake and reishi fungi and determine the morphological form of the isolated bacteria.

\section{MATERIALS AND METHODS}

Preparation of Culture Media for Bacteria and Fungi

There were three types of media used in this study, i.e., LB (Lactose Broth), NB (Nutrient Broth), and PDA (Potato Dextrose Agar) instant media with doses of $2.5 \mathrm{~g} / 100$ $\mathrm{mL}, 0.8 \mathrm{~g} / 100 \mathrm{~mL}$, and $3.9 \mathrm{~g} / 100 \mathrm{~mL}$, respectively. The mixture of each medium was homogenized on a magnetic stirrer for 5 minutes, then heated in a microwave for 15 minutes and sterilized in an autoclave at a temperature of $121^{\circ} \mathrm{C}$ for 15 minutes.

\section{Isolation and Purification of Bacteria}

Bacteria were isolated from reishi mushroom baglog originating from mushroom cultivation in Sumedang, West Java, and shiitake mushroom baglog from Sanggar Tani Media Agro Merapi, Yogyakarta Special Region. From each type of fungus, two baglogs were used as the population. The isolation method used was serial dilution ( $10^{-4}$ dilution factor). Bacteria isolated from the fungal baglog were then inoculated in LB agar medium by the pour plate method, each colony which had a different macroscopic morphology purified by the streak plate method to obtain a single colony. 
MORPHOLOGICAL IDENTIFICATION OF BACTERIA ISOLATED FROM MUSHROOM BAGLOG AND ITS EFFECT ON SHIITAKE (Lentinula edodes (Berk.) Pegler) AND REISHI (Ganoderma lucidum (Curtis) P. Karst)

MYCELIAL GROWTH

Ni Kadek Emi Sintha Dewi, I Gede Putu Wirawan, Made Sritamin

\section{Isolation of Shiitake and Reishi Fungi}

Fresh shiitake and reishi fruit bodies are used as a source of mycelium. Mushroom fruit bodies were sterilized with $70 \%$ alcohol, then split and cut into small pieces and inoculated on PDA medium for 7 days.

\section{Morphological Identification of Bacteria}

Observation of bacterial morphology

was carried out macroscopically and microscopically, including the shape, color, margin, and elevation of the colony, as well as gram staining and observation of the bacterial cell shape. Observation on a microscope using 1000x magnification with the aid of oil immersion to achieve greater clarity.

Preparation of Bacterial Cell-Free Extract

The bacteria isolates were inoculated on NB medium and shaken for 24 hours, then it was centrifuged for 30 minutes at $8000 \mathrm{rpm}$ at $4^{\circ} \mathrm{C}$ to obtain the bacterial cellfree extract.

\section{Test on Effect of Bacterial Cell-Free} Extract on Shiitake and Reishi Mycelial Growth

The bacterial cell-free extract was tested toward the growth of fungal mycelium. $2 \mathrm{~mL}$ of bacterial cell-free extract

was poured into $18 \mathrm{~mL}$ of PDA medium, then shiitake and reishi mycelium were inoculated on the medium. The diameter of the growing mycelium was measured on day 3 until the mycelium in the control treatment fully cover the medium in petri dish.

\section{RESULTS AND DISCUSSION}

\section{Result}

Isolation of Bacteria from Shiitake and

\section{Reishi Baglog}

The total bacteria isolated in this study were nine isolates, i.e, isolates M1A, M2A, S1A, S1B, S1C, S1D, S2A, S2B, and S2C. The letter $M$ shows the bacteria isolated from baglog originating from Merapi, while the letter $\mathrm{S}$ is the bacteria that isolated from baglog originating from Sumedang.

\section{Isolation of Shiitake and Reishi Mushrooms}

The results of mushroom isolation showed a variation in the growth rate of shiitake and reishi mycelium. Shiitake mycelium on PDA medium (without bacterial treatment) fully covered the medium on day 13 , while reishi mycelium on PDA medium (without bacterial treatment) fully covered the medium on day 9. 


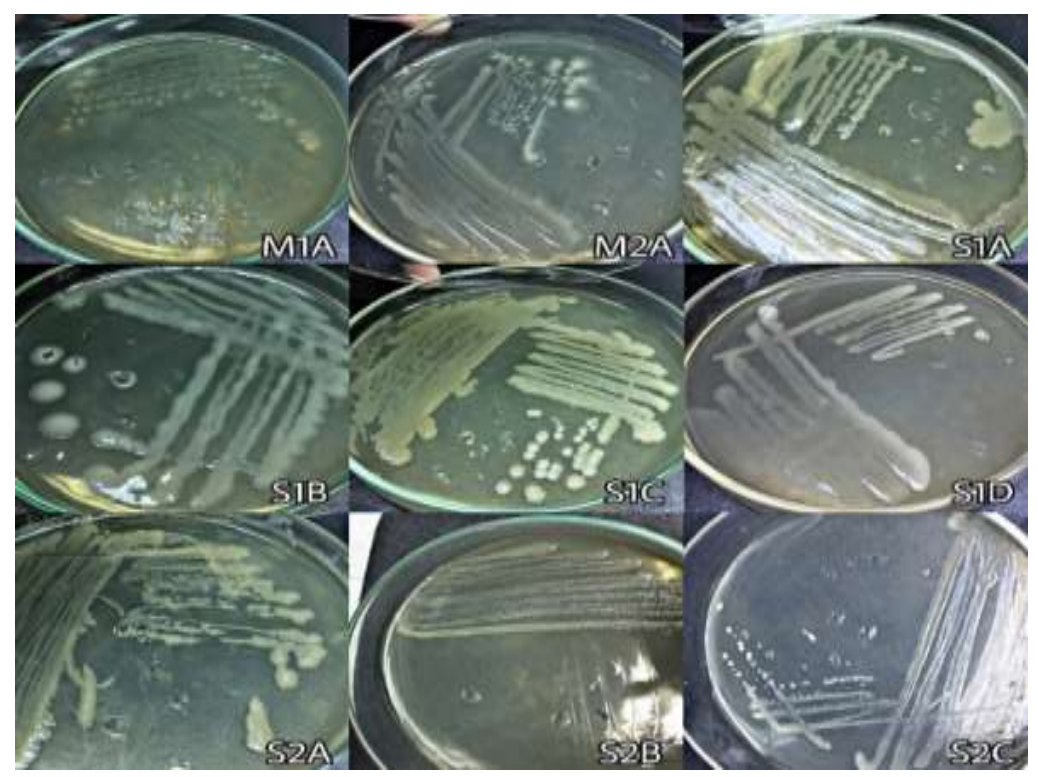

Fig. 1. Colony morphology of bacteria isolated form shiitake and reishi baglog

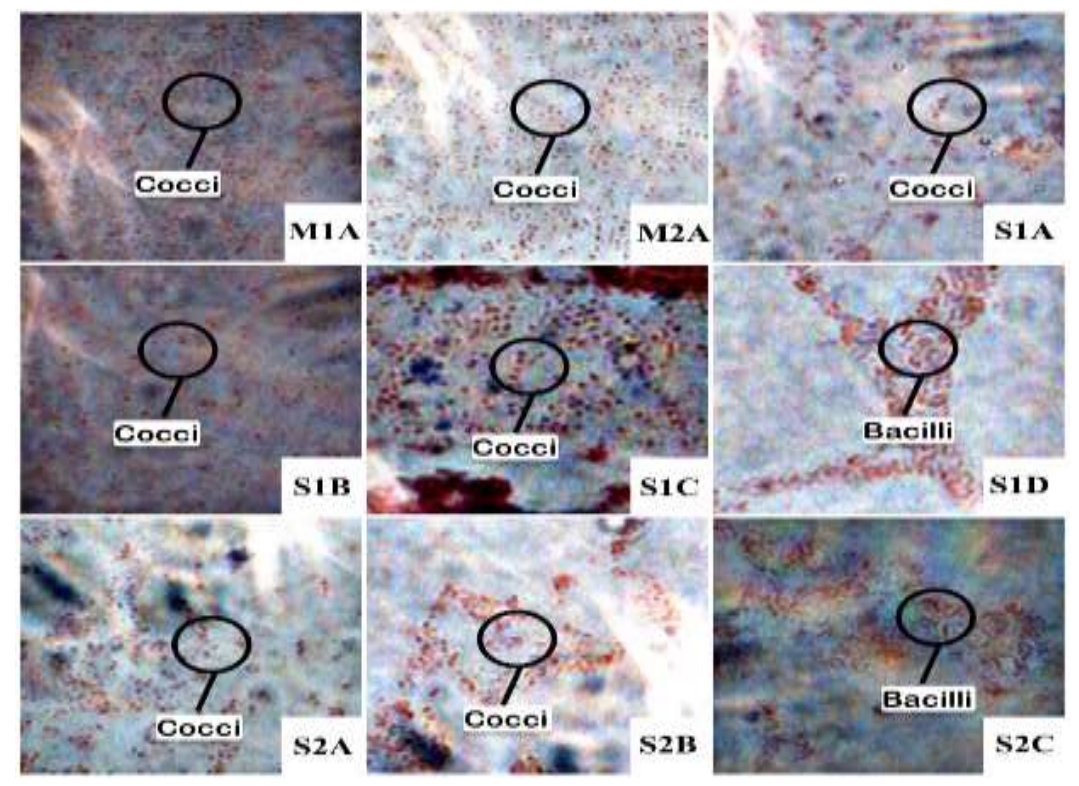

Fig. 2. Gram stained bacteria under microscope

\section{Morphological Identification of Bacteria}

Figure 1. shows the various macroscopic morphological characteristics in terms of colony shape, color, margin, and colony elevation.
Figure 2. shows all bacteria exibit red color after gram staining. Seven bacteria isolates were cocci (round-shaped cells), and two bacteria were bacilli (rod-shaped cells). 
Test on Effect of Bacterial Cell-Free grown on isolate S1C, S1D, S2A, and S2B. Extract on Shiitake and Reishi Mycelial Compared to the control treatment, there

\section{Growth}

Figure 3. shows that on the day 13 of observation, only the mycelium in the control fully covered the medium (on $9 \mathrm{~cm}$ diameter petri dish). It can be seen that there is a clear zone around the shiitake mycelium were no isolates potentially promote the growth of shiitake mycelium (Table 1). Shiitake mycelium on isolate M1A, M2A, S1 A, S1B, and S2C not growing from day 3 until the last day of observation (day 13).

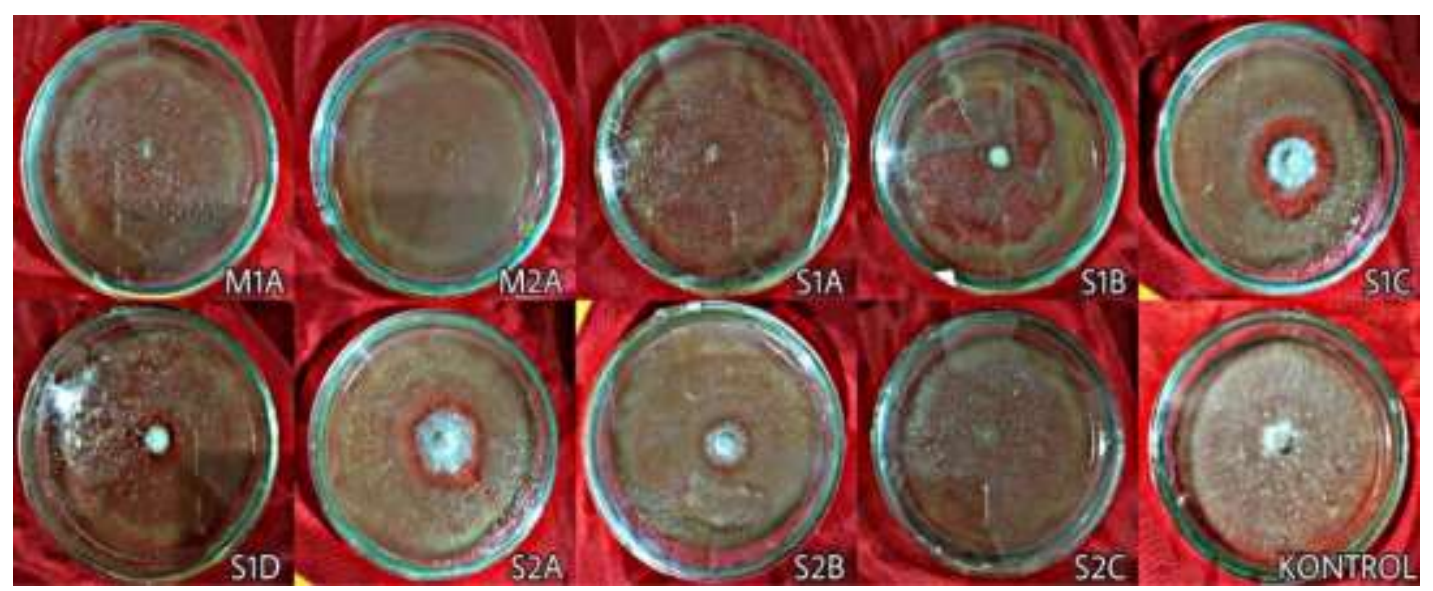

Fig. 3. Shiitake mycelium on PDA media contain bacterial cell-free extract on day 13 observation

Table 1 . The diameter of shiitake mycelium from day 3 to day 13 observation

\begin{tabular}{ccccccccccc}
\hline $\begin{array}{c}\text { Day of } \\
\text { observation }\end{array}$ & M1A & M2A & S1A & S1B & S1C & S1D & S2A & S2B & S2C & kontrol \\
\hline 3 & 0 & 0 & 0 & 0 & 1,2 & 1 & 1 & 1,3 & 0 & 1,4 \\
4 & 0 & 0 & 0 & 0 & 1,6 & 1,2 & 1,4 & 1,8 & 0 & 1,9 \\
5 & 0 & 0 & 0 & 0 & 1,9 & 1,2 & 1,6 & 2 & 0 & 2,7 \\
6 & 0 & 0 & 0 & 0 & 2,2 & 1,2 & 2 & 2,1 & 0 & 3,6 \\
7 & 0 & 0 & 0 & 0 & 2,6 & 1,2 & 2,3 & 2,1 & 0 & 4,4 \\
8 & 0 & 0 & 0 & 0 & 2,7 & 1,2 & 2,5 & 2,1 & 0 & 5,2 \\
9 & 0 & 0 & 0 & 0 & 2,7 & 1,2 & 2,8 & 2,1 & 0 & 6,2 \\
10 & 0 & 0 & 0 & 0 & 2,9 & 1,2 & 3,1 & 2,1 & 0 & 7,1 \\
11 & 0 & 0 & 0 & 0 & 2,9 & 1,2 & 3,2 & 2,1 & 0 & 7,9 \\
12 & 0 & 0 & 0 & 0 & 2,9 & 1,2 & 3,2 & 2,1 & 0 & 8,5 \\
13 & 0 & 0 & 0 & 0 & 2,9 & 1,2 & 3,2 & 2,1 & 0 & 9 \\
\hline
\end{tabular}




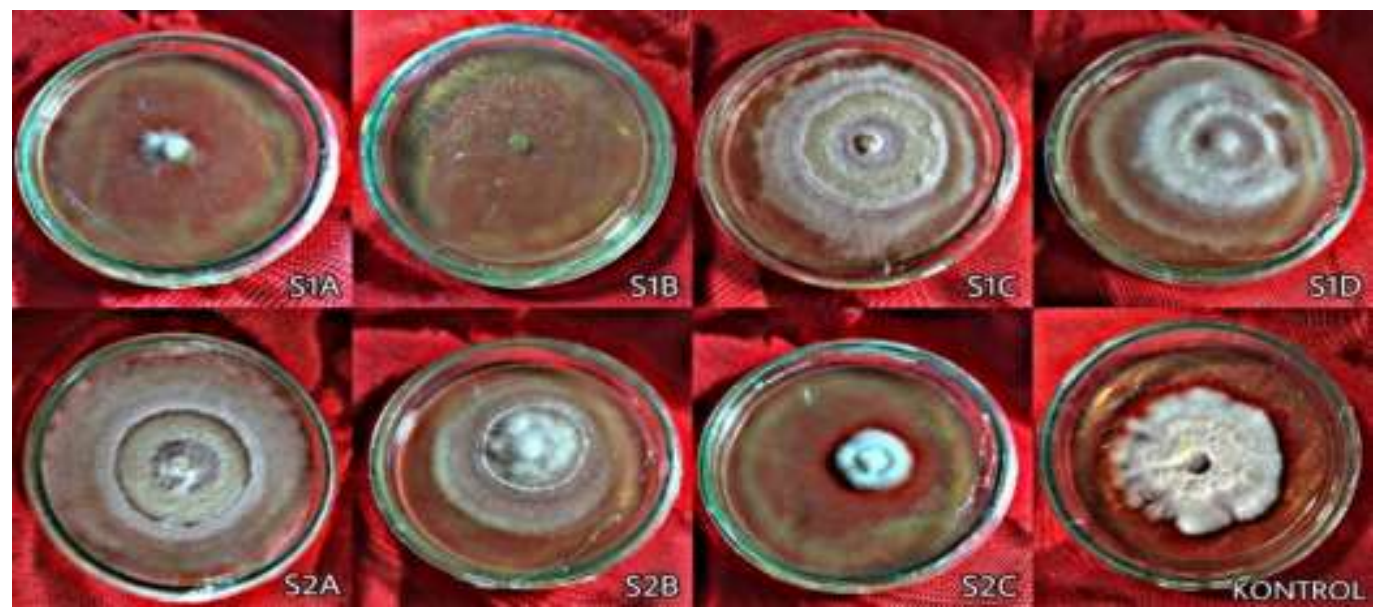

Fig. 4. Reishi mycelium on PDA media contain bacterial cell-free extract on day 6 observation

Table 2. The diameter of reishi mycelium from day 3 to day 9 observation

\begin{tabular}{ccccccccc}
\hline $\begin{array}{c}\text { Day of } \\
\text { observation }\end{array}$ & S1A & S1B & S1C & S1D & S2A & S2B & S2C & kontrol \\
\hline 3 & 0 & 0 & 6,2 & 5,1 & 6,1 & 5,4 & 1,2 & 2,8 \\
4 & 1 & 0 & 6,8 & 5,8 & 6,8 & 6,5 & 1,5 & 3,9 \\
5 & 1,3 & 0 & 7 & 6,5 & 7,3 & 6,8 & 2,1 & 5 \\
6 & 2,0 & 0 & 7,8 & 8,2 & 9 & 7 & 2,2 & 6 \\
7 & 3,2 & 0 & 9 & 9 & 9 & 8 & 3,3 & 7 \\
8 & 4,5 & 0 & 9 & 9 & 9 & 8,5 & 3,7 & 8,3 \\
9 & 5,7 & 0 & 9 & 9 & 9 & 8,7 & 4 & 9 \\
\hline
\end{tabular}

Figure 4. shows reishi mycelium on isolate S2A treatment had fully covered the medium on the day 6 of observation. Table 2 shows that the mycelium treated with isolate S1C, S1D, and S2A grew faster than mycelium in control treatment. Those isolates fully covered the media on day 7 th. Compared to the control treatment and other isolates, mycelium that treated with isolate
S1A, S1B, and S2C cell-free extract had much slower growth rate.

\section{Discussion}

The result of this study indicates that the number of bacteria isolates found in the reishi baglog is more than in the shiitake baglog. It is assumed that low bacteria count in shiitake baglog is caused by antimicrobial component in shiitake mushrooms, which 
MORPHOLOGICAL IDENTIFICATION OF BACTERIA ISOLATED FROM MUSHROOM BAGLOG AND ITS EFFECT ON SHIITAKE (Lentinula edodes (Berk.) Pegler) AND REISHI (Ganoderma lucidum (Curtis) P. Karst)

MYCELIAL GROWTH

Ni Kadek Emi Sintha Dewi, I Gede Putu Wirawan, Made Sritamin

suppresses bacterial growth. Kupcová et al. shaped cells. Based on the macroscopic and (2018) found that Lenthionine is a microscopic morphology, it is assumed that component of shiitake mushrooms that isolate S1D and S2C have similarities with exhibits antibacterial and antifungal activity. Pseudomonas (Public Health England,

Fungal mycelium isolated from the 2013) and Ewingella genus (Bukhari et al., fruiting body and grown on PDA media 2008).

without bacterial cell-free extract treatment showed that shiitake mycelial growth was slower than reishi. On day 9 of observation, the reishi mycelium had fully covered the medium $(9 \mathrm{~cm})$, whereas shiitake mycelium reached $9 \mathrm{~cm}$ in diameter on day 13. These results match those observed in the earlier study by Nguyen et al. (2019) and Quaicoe et al. (2014), who investigated the growth of reishi and shiitake mushroom, repectively.

Figure 1 shows the different macroscopic morphology of bacteria colonies. A bacteria colony is a visible mass formed by large numbers of bacteria. Each species of bacteria has a different colony morphology. Figure 2 shows that all bacteria isolates are gram negative as indicated by the appearance of a red color after the gram staining process. These results are consistent with those of Tejedor-Calvo et al. (2020), who found that the majority of the isolates, which isolated from the shiitake growing media, were gram negative. Isolate S1D and S2C are bacteria that have rod-

As shown in Table 1, there were no isolate that promote shiitake mycelial growth. It is suspected that the nine isolates are antagonistic bacteria that produce toxins that inhibit mycelial growth. Lo Cantore et al. (2015) found that $P$. tolaasii is a pathogen that produce volatile compounds such as methanetiol, dimethyl disulfide, and 1undecene, which inhibit growth and cause browning of mycelium in various fungi. There were clear zone around the shiitake mycelium that was grown on isolate $\mathrm{S} 1 \mathrm{C}$, S1D, S2A, and S2B (Figure 3). It is assumed that the clear zone formed due to extracellular enzymes produced by shiitake mycelium. Those enzymes can hydrolyze the free extract of bacterial cells containing organic compounds. Several types of extracellular enzymes produced by shiitake are cellulase, laminarinase, and xylanase (Mata et al., 2016).

It can be seen from the data in Table 2 that three isolates can be utilized as MGPB. The rapid growth of reishi mycelium in cell- 
free extracts of isolate S1C, S1D, and S2A is thought to be caused by the secretion of compounds that act as hormones or nutrients for fungal mycelium growth. Young et al. (2013) found that some MGPB are able to fix nitrogen, dissolve phosphate, and have cellulase activity associated with Agaricus blazei. On the other hand, the reishi mycelium in isolate S1A, S2C, and S1B bacteria did not grow well. It is assumed that those three isolates produce compounds that are toxic to reishi mycelium. Irma et al. (2018) found that $P$. aeruginosa bacteria inhibited the growth of the Ganoderma boninense fungus, where glucanase is a fungal cell wall degrading compound produced by $P$. aeruginosa (Suryadi et al., 2014).

Taken together, the results of this study indicated that the bacteria that potentially act as MGPB on reishi mushrooms have the opposite effect on shiitake by suppressing mycelium growth. Tejedor-Calvo et al. (2020) found that Ewingella americana is a bacterium that produces toxins and causes the degradation of shiitake mycelium. In contrast, the study by Zarenejad et al. (2012) discovered that fluorecent Pseudomonas spp. gave positive impact on the cultivation of Agaricus bisporus. Moreover, Oh et al. (2018) has indicated that E. americana can increase 194\% the growth of Tricholoma matsutake mycelium. Therefore, it seems that the interactions between bacteria and fungi are complex and specific. Within one genus or species of bacteria, it can cause different effects on fungi, stimulating growth and development, as well as damaging and being pathogenic to fungi.

\section{CONCLUSION}

This study has shown that two bacteria (isolate S1D and S2C) isolated from mushroom baglog had similarities to Pseudomonas and Ewingella genus. It was also shown that there were no bacteria that could stimulate the growth of shiitake mycelium; however, there are three isolate (S1C, S1D, and S2A) that have the potential as MGPB to reshi mushroom.

\section{ACKNOWLEDGEMENTS}

The authors are thankful to Central Laboratory for Genetic Resource and Molecular Biology Udayana University technicians for the necessary assistance in conducting this study. 
MORPHOLOGICAL IDENTIFICATION OF BACTERIA ISOLATED FROM MUSHROOM BAGLOG AND ITS EFFECT ON SHIITAKE (Lentinula edodes (Berk.) Pegler) AND REISHI (Ganoderma lucidum (Curtis) P. Karst)

MYCELIAL GROWTH

Ni Kadek Emi Sintha Dewi, I Gede Putu Wirawan, Made Sritamin

\section{REFERENCES}

Abou-Zeid, M. A. (2012). Pathogenic variation in isolates of Pseudomonas causing the brown blotch of cultivated mushroom, Agaricus bisporus. Brazilian Journal of Microbiology, 43(3), 1137-1146. https://doi.org/10.1590/S151783822012000300041

Bukhari, S. Z., Hussain, W. M., Fatani, M. I., \& Ashshi, A. M. (2008). Multi-drug resistant Ewingella americana. Saudi Med. Journal.

Duran-Rivera, B., Rojas-Rodas, F., SilvaLopez, W., Gomez-Suarez, C., \& Castro-Restrepo, D. (2020). Molecular identification of shiitake [Lentinula edodes Berk (Pegler)] and production of secondary metabolites with biotechnological potential. Revista Bionatura, 5(3), 1183-1188. https://doi.org/10.21931/RB/2020.05.0 3.3

Febriansyah, E., Saskiawan, I., Mangunwardoyo, W., Sulistiyani, T. R., \& Widhiya, E. W. (2018). Potency of growth promoting bacteria on mycelial growth of edible mushroom Pleurotus ostreatus and its identification based on 16S rDNA analysis. AIP Conference Proceedings, 2002.

https://doi.org/10.1063/1.5050119

Irma, A., Meryandini, A., \& Rupaedah, B. (2018). Biofungicide producing bacteria: An in vitro inhibitor of Ganoderma boninense. HAYATI Journal of Biosciences, 25(4), 151159.

https://doi.org/10.4308/hjb.25.4.151

Lo Cantore, P., Giorgio, A., \& Iacobellis, N. S. (2015). Bioactivity of volatile organic compounds produced by Pseudomonas tolaasii. Frontiers in
Microbiology, $\quad 6(\mathrm{OCT}), \quad 1-14$. https://doi.org/10.3389/fmicb.2015.01 082

Mata, G., Salmones, D., \& Pérez-Merlo, R. (2016). Actividad de las enzimas hidrolíticas en cepas del hongo shiitake (Lentinula edodes) cultivadas en pulpa de café. Revista Argentina de Microbiologia, 48(3), 191-195. https://doi.org/10.1016/j.ram.2016.05. 008

Nguyen, B. T. T., Ngo, N. X., Le, V. Van, Nguyen, L. T., Kana, R., \& Nguyen, H. D. (2019). Optimal culture conditions for mycelial growth and fruiting body formation of Ling Zhi mushroom Ganoderma lucidum strain GA3. Vietnam Journal of Science, Technology and Engineering, 61(1), 62-67.

https://doi.org/10.31276/vjste.61(1).62 $-67$

Oh, S. Y., Kim, M., Eimes, J. A., \& Lim, Y. W. (2018). Effect of fruiting body bacteria on the growth of Tricholoma matsutake and its related molds. PLoS ONE, 13(2), 1-15. https://doi.org/10.1371/journal.pone.0 190948

Quaicoe, E. H., Amoah, C., Obodai, M., \& Odamtten, G. T. (2014). Nutrient Requirements And Environmental Conditions For The Cultivation Of The Medicinal Mushroom (Lentinula Edodes) (Berk.) In Ghana. International Journal of Scientific \& Technology Research, 3(12), 44-50.

Ruthes, A. C., Smiderle, F. R., \& Iacomini, M. (2016). Mushroom heteropolysaccharides: A review on their sources, structure and biological effects. Carbohydrate Polymers, 136, 358-375.

https://doi.org/10.1016/j.carbpol.2015. 08.061 
Suryadi, Y., Susilowati, D. N., Lestari, P., Priyatno, T. P., Samudra, I. M., Hikmawati, N., Mubarik, D. N. R., \& Mubarik, N. R. (2014). Characterization of bacterial isolates producing chitinase and glucanase for biocontrol of plant fungal pathogens. Journal of Agricultural Technology, 10(4), 983-999. http://www.ijataatsea.com

Tejedor-Calvo, E., García-Barreda, S., Sánchez, S., \& Marco, P. (2020). Effect of bacterial strains isolated from stored shiitake (Lentinula edodes) on mushroom biodeterioration and mycelial growth. Agronomy, 10(6). https://doi.org/10.3390/agronomy1006 0898

Vitak, T., Yurkiv, B., Wasser, S., Nevo, E., \& Sybirna, N. (2017). Effect of medicinal mushrooms on blood cells
https://doi.org/10.24843/IJBB.2021.v09.i01.p04

under conditions of diabetes mellitus. World Journal of Diabetes, 8(5), 187. https://doi.org/10.4239/wjd.v8.i5.187

Young, L. Sen, Chu, J. N., Hameed, A., \& Young, C. C. (2013). Cultivable mushroom growth-promoting bacteria and their impact on agaricus blazei productivity. Pesquisa Agropecuaria Brasileira, 48(6), 636-644. https://doi.org/10.1590/S0100204X2013000600009

Zarenejad, F., Yakhchali, B., \& Rasooli, I. (2012). Evaluation of indigenous potent mushroom growth promoting bacteria (MGPB) on Agaricus bisporus

production. World Journal of Microbiology and Biotechnology, 28(1), 99-104. https://doi.org/10.1007/s11274-0110796-1 